\title{
15
}

\section{Non-Nuclear Allies and Declaratory Policy: The NATO Experience}

\author{
Michael Rühle
}

Extended nuclear deterrence, being the willingness of the United States to commit nuclear weapons to the defence of its allies, has become a central pillar of the international order. Today, over 30 countries in Europe and the Asia-Pacific region are considered to be under the US 'nuclear umbrella'. Critics of this concept often assert that the US would never risk its own destruction in order to protect its allies. Yet, despite this inherent credibility dilemma, the US and its allies consider this arrangement to be of existential importance. As Lawrence Freedman observes, nuclear weapons 'can have a deterrent effect well beyond their logical limits'. ${ }^{1}$ By explicitly extending its nuclear (and conventional) deterrence to other countries, Washington sends a powerful signal that it regards their security as a fundamental national security interest. ${ }^{2}$

\footnotetext{
1 Lawrence Freedman, 'Disarmament and Other Nuclear Norms', Washington Quarterly 36(2), 2013, 102, doi.org/10.1080/0163660X.2013.791085.

2 Moreover, the 'nuclear umbrella' also relieves allies from the need to develop nuclear weapons of their own. While the causality between extended deterrence and non-proliferation is sometimes questioned, some cases demonstrate that US allies who felt abandoned by Washington had started nuclear programs, only to halt them once relations with the US had recovered. See Rebecca K.C. Hersman and Robert Peters, 'Nuclear U-Turns: Learning from South Korean and Taiwanese Rollback', Nonproliferation Review 13(3), November 2006, 539-53, doi.org/10.1080/10736700601071629.
} 
The specific implementation of US extended nuclear deterrence commitments varies considerably. In the Asia-Pacific region, Washington maintains bilateral relationships with like-minded but diverse democracies such as Australia and Japan. In Europe, by contrast, Washington's nuclear relationships are largely managed through the North Atlantic Treaty Organization (NATO), an alliance of currently 30 countries with a longstanding shared 'culture' of nuclear cooperation and planning. These different regional approaches are also reflected in nuclear declaratory policy. Whereas NATO statements are negotiated among 30 allies, pronouncements on nuclear matters in the Indo-Pacific region reflect the individual nature of each bilateral relationship. However, despite these differences, the basic challenges surrounding nuclear declaratory policy are quite similar. Based on NATO's experience, which dates back over seven decades, this chapter seeks to identify the most pertinent challenges.

\section{The Multi-Directional Character of Declaratory Policy}

Political declarations on security matters, whether issued by individual governments or by coalitions of states, usually have several recipients: one's own political elites; one's broader population; one's (real and potential) opponents; and - in the case of the US-one's allies benefiting from extended deterrence protection, including their political elites and publics. ${ }^{3}$ Ideally, each of these addressees would understand the message exactly as its originators intended. The political elites would be reassured that 'radical departures in policy have been avoided and that no commitments have been made to anything that will cause upset at home or, even worse, require extra funds'. ${ }^{4}$ The broader population, it may be hoped, would come away with the comforting feeling that their security was being taken care of. The allies would be reassured about the continued US commitment to their security. And the opponents would be impressed — and deterred - by a strong sign of national or collective resolve. In practice, however, these lines are often blurred.

3 On the complexity of US extended deterrence messaging, see Brad Roberts, The Case for US Nuclear Weapons in the 21st Century (Stanford: Stanford University Press, 2015), 214-34, doi.org/10.1515/9780804797153.

4 Lawrence Freedman, The Primacy of Alliance: Deterrence and European Security, Proliferation Papers No. 46, March-April 2013, www.ifri.org/sites/default/files/atoms/files/pp46freedman.pdf. 
As far as alliances such as NATO are concerned, the major goal of such a communications exercise is not the exposition of military-strategic detail, but rather the mutual reaffirmation of the alliance's broader purpose and, above all, unity. The German term 'Selbstvergewisserung' (slightly awkwardly translated as 'self-assurance') perhaps captures it best: for an alliance of 30 countries, with governments from across the entire political spectrum, unity is the most precious asset. More than any specific instruments of military power, it is the political power of a cohesive coalition of like-minded states that serves as the ultimate key to security. This is not to say that military questions are merely an afterthought; however, they must never be seen to dominate (and possibly derail) regular alliance business.

This primacy of alliance unity over military posture is particularly obvious when it comes to nuclear matters. After all, it is here that asymmetries among allies-in terms of military power but also in terms of statusare most obvious, and where even a small rhetorical misstep by one ally can cause massive damage to alliance cohesion. As the history of NATO has amply demonstrated, what may come across as a statement of resolve designed to impress an opponent and thus strengthen nuclear deterrence may also incite fear and antagonism among one's own population. For an alliance that features three nuclear powers (who are also permanent members of the United Nations Security Council) and 27 non-nuclear states, agreeing on proclamations on nuclear matters is sometimes akin to walking on eggshells.

The NATO allies' careful stance when it comes to public declarations on nuclear matters is not the result of an assumed blanket anti-nuclear bias among their own populations. While numerous opinion polls suggest that such a bias does indeed exist, the respondents' answers are highly dependent on the wording of the questions asked by the pollsters and are thus of little value in terms of guiding established policy. ${ }^{5}$ Even in countries with strong anti-nuclear civil society groups that have made nuclear weapons a prominent election issue, nuclear weapons are not an issue that, in themselves, would be the determining factor in election outcomes.

5 See Thomas W. Graham, American Public Opinion on NATO, Extended Deterrence, and Use of Nuclear Weapons: Future or Fission? (Lanham: University Press of America, 1989). Graham notes that, when it comes to nuclear weapons, people often hold multiple contradictory beliefs. On the rise and fall of the US Freeze Movement in the 1980s, see J. Michael Hogan, The Nuclear Freeze Campaign: Rhetoric and Foreign Policy in the Telepolitical Age (East Lansing: Michigan State University Press, 1994). For an overview of the cultural context of nuclear weapons and nuclear energy, see Spencer R. Weart, The Rise of Nuclear Fear (Cambridge: Harvard University Press, 2012). 
Other factors, such as the economy, matter much more. ${ }^{6}$ However, as has been demonstrated many times, within NATO as well as within the Australia, New Zealand, United States Security Treaty (ANZUS), nuclear weapons can become an issue for domestic political skirmishes and party politics. ${ }^{7}$ Hence, the major reason for the care exerted by allies in their public pronouncements is the desire to offer no cause for-inadvertent or deliberate-misunderstandings that could result in political disputes. ${ }^{8}$

\section{The Nuclear Paradox}

Nuclear weapons represent the ultimate paradox. Their enormous destructive power makes their use potentially suicidal, yet it is precisely these possible disastrous consequences that exercise restraint on the behaviour of states. Thus, while the nuclear age has seen many conventional wars, no nuclear powers have used nuclear weapons against each other. Nuclear deterrence cannot prevent every kind of war, but it is always present when existential issues are at stake. As former US defence secretary James Schlesinger observed, in this sense, nuclear weapons are being 'used' every day. ${ }^{9}$ NATO, for its part, has repeatedly stated that as long as nuclear weapons exist, it will remain a nuclear alliance. ${ }^{10}$

6 This is not to say that nuclear weapons per se are not an important factor in elections. See, for example: Ian McAllister and Anthony Mughan, 'The Nuclear Weapons Issue in the 1983 British General Election', European Journal of Political Research 14, 1986, 651-67, doi.org/10.1111/j.1475-6765.1986. tb00854.x.

7 On the demise of ANZUS due to a change of government in one member state, see Gerald Hensley, Friendly Fire: Nuclear Politics and the Collapse of ANZUS, 1984-1987 (Auckland: Auckland University Press, 2013).

8 In addition to communiqués, speeches and other statements, high-level NATO officials can also send political messages to specific audiences. For example, when a debate started to heat up in Germany over that country's continued participation in nuclear-sharing arrangements, the NATO secretary general published an article in a major German daily that underlined Germany's crucial role. See Jens Stoltenberg, 'Germany's Support for Nuclear Sharing is Vital to Protect Peace and Freedom', NATO, 11 May 2020, www.nato.int/cps/en/natohq/opinions_175663.htm?selectedLocale=en, originally published by Frankfurter Allgemeine Zeitung.

9 See Melanie Kirkpatrick, 'Why We Don't Want a Nuclear-Free World', Wall Street Journal, 13 July 2009, www.wsj.com/articles/SB124726489588925407.

10 The term 'nuclear alliance' was first used in NATO's 2010 Strategic Concept, see Strategic Concept for the Defence and Security of the Members of the North Atlantic Treaty Organization, adopted by Heads of State and Government at the NATO Summit in Lisbon 19-20 November 2010, NATO, www.nato.int/strategic-concept/pdf/Strat_Concept_web_en.pdf. However, a few months earlier, Hillary Clinton, then US secretary of state, said at a meeting of NATO foreign ministers in Tallinn:

We should recognize that as long as nuclear weapons exist, NATO will remain a nuclear alliance ... As a nuclear alliance, sharing nuclear risks and responsibilities widely is fundamental.

Quoted in Mark Landler, 'US Resists Push by Allies for Tactical Nuclear Cuts', The New York Times, 22 April 2010, www.nytimes.com/2010/04/23/world/europe/23diplo.html. 
Orthodox Western security policy seeks to utilise the destructive potential of nuclear weapons to prevent war. This task is considered rather easy when it comes to protecting the homeland of a nuclear power, as nuclear retaliation in the face of an existential threat appears credible. By contrast, extending nuclear deterrence protection to non-nuclear allies is a much more complex matter, since their security is not necessarily essential for the survival of the protector. Extended nuclear deterrence is therefore burdened with perennial doubts as to its credibility. This dilemma was perhaps best captured by Denis Healey, the United Kingdom's minister for defence in 1964-70, in what he termed the 'Healey Theorem': 'It takes only five per cent credibility of American retaliation to deter the Russians, but ninety-five per cent credibility to reassure the Europeans. ${ }^{11}$

To minimise the uncertainties associated with the concept of extended nuclear deterrence, the non-nuclear ally seeking nuclear protection will try to obtain an ironclad commitment by its nuclear guarantor that the latter will be willing and able to use nuclear weapons in defence of its ally. By contrast, the nuclear protector will seek to minimise any risk of becoming entrapped in any kind of escalatory automatism and will thus try to protect its autonomous decision-making. In the same vein, while the non-nuclear ally will seek commitments from its protector that a military response to an act of aggression will be swift and decisive, the protector will want to preserve a degree of flexibility to contemplate its actions and assess their potential consequences.

Despite sometimes long and controversial debates among allies, this inherent tension between the expectations of the non-nuclear allies and the hesitation of the US to satisfy them in full could never be completely resolved. However, in the late 1960s, a workable compromise was finally agreed upon: US nuclear weapons in Europe would reinforce the credibility of the US commitment, while European delivery means and a newly created Nuclear Planning Group would address the European desire to exert influence on US nuclear planning. ${ }^{12}$ These nuclear-sharing arrangements would also ease European, notably West German, worries with regard to signing the Treaty on the Non-Proliferation of Nuclear Weapons (NPT): the very notion of 'sharing' would qualify the NPT's

11 Denis Healey, The Time of My Life (London: Michael Joseph, 1989), 243.

12 See Timothy Andrews Sayle, 'A Nuclear Education: The Origins of NATO's Nuclear Planning Group', Journal of Strategic Studies 43(6-7), 2020, 920-56, doi.org/10.1080/01402390.2020.18185 60. Also see the contribution of Alexander Mattelaer in this volume. 
inherently discriminatory character by suggesting, at least in intent, a tendency towards equalising the status of allies. In conformity with the logic of the NPT, the US would retain control of its nuclear arsenal, yet European allies would participate in the nuclear mission, both materially and conceptually. ${ }^{13}$

\section{Deterrence versus Reassurance}

The intra-alliance debates that led to these compromises were sometimes fierce, but they never fully made it into the public discussions. This changed in the late 1970s, when certain procurement decisions by NATO and individual governments became the subject of intense public scrutiny - and opposition. US plans to deploy a new type of nuclear weapon in West Germany had to be cancelled due to political and party resistance in Bonn as well as public concerns. While the controversy about the 'neutron bomb' was largely a bilateral US-West German affair, the use of slogans and imagery to exploit perennial nuclear fears turned out to be a harbinger of a much more severe controversy that followed shortly thereafter and led to a major crisis in the Western alliance: NATO's socalled dual-track decision of December 1979. ${ }^{14}$

The NATO allies, worried about the deployment of a new category of Soviet 'Eurostrategic' nuclear missiles that might challenge the nuclear 'coupling' across the Atlantic, decided to deploy their own new nuclear missiles in this range category. Even though this decision was eventually combined with an arms control offer to Moscow, NATO's 'dual-track' decision led to a crisis that still shapes NATO's cautious approach to nuclear matters. For the first time in decades, issues of nuclear deterrence, including the consequences of the employment of nuclear weapons, were discussed by a broader public that appeared totally unprepared. Already worried by the breakdown of détente in general, and careless talk by members of the Reagan administration about a 'winnable' nuclear war in particular, many Europeans became outright afraid of an impending war that would engulf Europe while sparing the 'sanctuaries' of the Soviet

13 France is not - and has never been - a member of the Nuclear Planning Group.

14 Kristina Spohr Readman, 'Germany and the Politics of the Neutron Bomb, 1975-1979',

Diplomacy \& Statecraft 21(2), 2010, 259-85, doi.org/10.1080/09592296.2010.482473. 
Union and the US. ${ }^{15}$ This debate revealed, in the words of British military historian Michael Howard, that the focus of Western governments on acquiring new military capabilities to restore deterrence had led them to lose sight of the political imperative of reassuring their own publics. ${ }^{16}$

This discussion need not be reviewed in detail. ${ }^{17}$ However, it generated several key lessons that still determine NATO's approach to the handling of the nuclear dossier. The first lesson was that an extensive public debate on nuclear deterrence should be avoided. A rational discussion on nuclear employment options may be possible among like-minded experts, but no Western government should expect that its broader constituency would be willing to buy into the logic of 'deliberate escalation', 'limited nuclear employment' or similar intellectual constructs. As NATO's dual-track crisis vividly demonstrated, while the basic logic of deterrence is not difficult to grasp, public agreement with established policies tends to wane the more detailed the policy rationale becomes. With this backdrop, the 'democratization of national security issues' is but a euphemism for acrimonious debates that could jeopardise allied cohesion. ${ }^{18}$

The second lesson was that a debate over nuclear security was not just a debate between NATO governments and their publics, but also included the Soviet Union as well as Western 'counter-experts' who challenged NATO nuclear orthodoxy and often reinforced Moscow's arguments. ${ }^{19}$ Moreover, some citizens of Western nations were susceptible to Soviet threats, in particular to Moscow's claim that any newly deployed US ballistic missiles or cruise missiles, due to their alleged first strike

15 For an excellent overview, see David S. Yost, 'The Delegitimization of Nuclear Deterrence?', Armed Forces and Society 16(4), Summer 1990, 487-508. For a detailed discussion on the various protest movements and their beliefs, see Benjamin Ziemann, 'A Quantum of Solace? European Peace Movements during the Cold War and their Elective Affinities', Archiv für Sozialgeschichte 49, 2009, 351-89.

16 See Michael Howard, 'Reassurance and Deterrence: Western Defence in the 1980s', Foreign Affairs 61, 1982-83, 311.

17 For an overview, see Stephanie Freeman, 'The Making of an Accidental Crisis: The United States and the NATO Dual-Track Decision of 1979', Diplomacy \& Statecraft 25, 2014, 331-55, doi.org/10.1080/09592296.2014.907071; Josef Joffe, 'Peace and Populism: Why the European Anti-Nuclear Movement Failed', International Security 11(4), Spring 1987, 3-40, doi.org/10.2307/2538836. On the Dutch 'Hollanditis', see Ruud van Dijk, 'A Mass Psychosis: The Netherlands and NATO's Dual-Track Decision, 1978-1979', Cold War History 12(3), 2012, 381-405, doi.org/10.1080/14682745.2011.621750.

18 Richard Flickinger, 'Public Opinion: The Peace Movement and NATO Missile Deployment', Peace \& Change 9(1), 1983, 26.

19 See the exchange between Jeffrey Herf, Gert Krell, Harald Müller and Matthew Evangelista in: 'Correspondence', International Security 11(2), 1986, 193-215, doi.org/10.2307/2538966. 
capabilities', would inevitably become the initial targets of a Soviet strike. NATO governments, parliamentarians and military experts were forced to engage in public debates on detailed nuclear scenarios, in which the political character of the East-West competition got lost. Soviet leaders had sensed correctly that raising the spectre of 'Euroshima' would divert attention away from systemic differences between open and closed societies. In short, with 'mutual survival' becoming the key concern, the East-West relationship became de-politicised.

The third, and in many ways most painful, lesson was that nuclear fears trumped alliance politics. The whole point of NATO's dual-track decision-namely, to prevent a 'de-coupling' of Europe from the US-almost disappeared in the heated debate. Instead, the US, the main provider of extended nuclear deterrence for NATO Europe, was criticised as 'trigger happy', while the Soviet Union, which had caused the entire predicament through its massive conventional and nuclear force modernisation program, was seen by many as a victim of US belligerence. Instead of appreciating NATO as a security blanket, citizens of alliance nations perceived NATO as a political-military straitjacket that held the European member states hostage to American omnipotent fantasies. ${ }^{20}$ Even if the crisis ultimately had a happy ending-Moscow finally accepted Western proposals, resulting in the historic 1987 Intermediate-Range Nuclear Forces (INF) Treaty that banned this entire weapon categoryallied governments had learned that a public discussion on the nuclear dossier risked becoming emotionally and politically counterproductive and, hence, had to be avoided. The price they had to pay for ending this episode-namely, to allow arms control to trump nuclear strategy considerations-was considerable, but seemed tolerable. ${ }^{21}$

These lessons remain valid and have been assimilated-consciously or subconsciously_by NATO allies. For example, in 2019, Russian violations of the INF Treaty by deploying a new missile type were met with a response that was measured both in tone and in substance. Rather than espousing a 'tit-for-tat' logic, which would have called for NATO's deployment of similar ground-based nuclear-capable missile systems, the allies declared that they would respond with a range of

20 See Andreas Lutsch, 'Merely "Docile Self-Deception"? German Experiences with Nuclear Consultation in NATO', Journal of Strategic Studies 39, 2016, 535-58, doi.org/10.1080/01402390. 2016.1168014.

21 See Andreas Lutsch, 'The Zero Option and NATO's Dual-Track Decision: Rethinking the Paradox', Journal of Strategic Studies 43(6-7), 2020, 27, doi.org/10.1080/01402390.2020.1814259. 
non-nuclear measures. ${ }^{22}$ While the Russian deployments were not yet on a numerical par with the SS-20 deployments in the late 1970s, NATO's response nipped any potential controversy in the bud.

\section{Signalling}

Some observers have argued that NATO's declaratory statements are too anodyne to allow for internal strategy development, let alone serious signalling towards potential opponents, pointing to 'a disconnect between agreed-upon, but ambiguous, policy statements, and precise and doctrinal direction necessary to guide action, a significant "gap". ${ }^{23}$ Others point to what they believe to be inconsistencies in NATO's messaging-for example, by declaring that NATO's nuclear posture is adequate even while agreeing that the state of European security had changed for the worse. ${ }^{24}$

However, such criticism reveals a fundamental misunderstanding of intra-alliance dynamics. For example, to believe that NATO would publicly declare that Russia's illegal annexation of Crimea in spring 2014 had rendered NATO's nuclear policy and posture inadequate, requiring a fundamental overhaul of this delicate dossier, reflects a simplistic-if common-expectation that the allies would stand to benefit from making such pronouncements. NATO's experience suggests the exact opposite. If changes in the strategic environment occur, one may indeed need to start reviewing certain established policies; however, given the potential difficulties (and the prospective long time frame for enacting change), the first (and most important) response vis-a-vis the public must be to reassure, not to alarm. ${ }^{25}$

22 See Rose Gottemoeller, 'NATO Nuclear Policy in a Post-INF World', Speech by NATO Deputy Secretary General at the University of Oslo, 9 September 2019, www.nato.int/cps/en/natohq/ opinions_168602.htm?selectedLocale=en.

23 Andrew Corbett and Annamarie Bindenagel Šehović, Acculturation of the Core Concepts of European Security, NATO Science and Technology Organization, SAS-141.

24 For example, Karl-Heinz Kamp notes that NATO's 2012 Deterrence and Defence Posture Review described NATO's nuclear posture as 'adequate', yet even a game-changing event such as Russia's illegal annexation of Crimea in 2014 had not changed NATO's evaluation. See Karl-Heinz Kamp, 'Nuclear Reorientation of NATO', NATO Defense College Commentary, 5 February 2018, www.ndc.nato.int/download/downloads.php?icode $=537$.

25 Military details are principally dealt with in classified follow-on documents. By the same token, changes in NATO's nuclear planning and posture-such as changing alert levels and exercise scenarios, providing non-nuclear support for nuclear missions or the procurement of new dualcapable aircraft_- proceed without detailed references in public documents. However, many of them are known through certain think tanks and other non-governmental sources. 
NATO nuclear declaratory policy may indeed be fairly general, with certain key phrases being repeated literally for decades. However, while the most cryptic parts of this esoteric communication among allies need to be 'decoded' ${ }^{26}$ it is not too difficult to identify elements of change and gauge their political meaning. One example was the characterisation of nuclear weapons as 'weapons of last resort ${ }^{27}$ in the 1990 London Summit Declaration. This new terminology was seen by some as risky, as it could have been read as a substantial downgrading of nuclear weapons and nuclear deterrence. ${ }^{28}$ Accordingly, the term 'last resort' did not appear in subsequent declarations. However, in retrospect, the choice of the term at this specific historical juncture appears prescient: to persuade Moscow not to try to arrest the political changes that were happening at home and in its Eastern European glacis, it had to be assured about NATO's benign intentions. The downgrading of the salience of nuclear weapons implicit in the phrase 'last resort' sent the desired signal.

A similar logic applied to the nuclear Deterrence and Defence Posture Review (DDPR) - a process initiated in 2010 and concluded in 2012. The main rationale for this process was the need to consolidate NATO's nuclear 'acquis' in light of certain countervailing developments, such as US President Obama’s 'Prague agenda' on nuclear disarmament. This US policy had led some European NATO governments to envisage the withdrawal of European-based US nuclear weapons from the continent. Contrary to some expectations, however, the DDPR process turned into a strong reaffirmation of NATO's nuclear basics, all the more so as the US itself rejected any hasty disarmament moves in the NATO context. By encouraging the 'broadest possible participation of allies'

26 Freedman, The Primacy of Alliance, 8.

27 With the total withdrawal of Soviet stationed forces and the implementation of a CFE agreement, the Allies concerned can reduce their reliance on nuclear weapons. These will continue to fulfill an essential role in the overall strategy of the Alliance to prevent war by ensuring that there are no circumstances in which nuclear retaliation in response to military action might be discounted. However, in the transformed Europe, they will be able to adopt a new NATO strategy making nuclear forces truly weapons of last resort.

'Declaration on a Transformed North Atlantic Alliance', Issued by the Heads of State and Government participating in the meeting of the North Atlantic Council ('The London Declaration'), 5-6 July 1990, www.nato.int/cps/en/natohq/official_texts_23693.htm.

28 Accordingly, British Prime Minister Thatcher explained that, in order to keep 'the full deterrent effect', the phrase 'last resort' should be construed in the context of 'the comprehensive concept phraseology' employed in the entire paragraph of the Summit Declaration. See Margaret Thatcher, 'Press Conference after London NATO Summit', 6 July 1990, www.margaretthatcher.org/ document/108139. The author is indebted to David Yost for his research on this episode. 
in nuclear sharing and related arrangements, allies provided a carefully worded, yet clear statement about the continued value of these unique nuclear arrangements.

The DDPR thus rebuffed those voices from politics and academia who had been arguing that nuclear-sharing arrangements were obsolescent and thus could safely be discarded. Moreover, rather than defining arms control and non-proliferation as NATO's overarching objectives, the DDPR embedded these concepts in the broader context of NATO's comprehensive deterrence and defence policies. ${ }^{29}$ In sum, the carefully worded endorsement of NATO's existing nuclear policy and posture in the DDPR reined in the critical views and thus helped maintain alliance unity on the nuclear dossier.

A final example is the unusually strong emphasis on nuclear deterrence in the 2016 Warsaw Summit Declaration. While much of the language was known from previous communiqués, the sheer amount of language on nuclear matters, as well as the way in which certain statements were presented, was not lost on Western observers and, presumably, any potential adversaries. ${ }^{30}$

\section{Defending Nuclear Core Principles}

NATO nuclear policy statements may be general, yet when it comes to defending the basic principles of the alliance's nuclear character-as opposed to military-operational details_allies are willing to speak up. For example, NATO's collective response to the Treaty on the Prohibition of Nuclear Weapons (TPNW) was tougher and more categorical than some observers had expected. Having recognised that this treaty, despite its professed universal vocation, is largely intended as an assault on Western, notably NATO nuclear policies, allies resorted to rather unambiguous language. When the treaty entered into force, allies restated their collective

29 SeeMichaelRühle, TheBroader ContextofNATO's NuclearPolicyandPosture, NATODefenseCollege Research Report No. 89, January 2013, www.ndc.nato.int/download/downloads.php?icode=366. 30 See Stephan Frühling, 'NATO Summit: Collective Defence and Nuclear Deterrence', Australian Institute of International Affairs, 14 July 2016, www.internationalaffairs.org.au/australianoutlook/ nato-summit-collective-defence-nuclear-deterrence/. 
opposition, 'as it does not reflect the increasingly challenging international security environment and is at odds with the existing non-proliferation and disarmament architecture'. ${ }^{31}$

Critics were quick to point out that this 'tone-deaf' rejection of the TPNW would make it more difficult to strike a middle ground. ${ }^{32}$ However, the genesis of the treaty, as well as the language employed by some of its supporters, suggests that the very idea of a middle ground is, to say the least, questionable. The treaty seeks to outlaw nuclear cooperation and thus appears to be directed, first and foremost, against the US and its allies. ${ }^{33}$ Moreover, the fact that some long-time partner countries of NATO, who initially had lobbied for the de-legitimisation of nuclear weapons, have started to rethink their national approaches, suggests that NATO's unambiguous messaging will not undermine the success of its partnership policies. ${ }^{34}$

Finally, contrary to the impression that TPNW advocates are trying to convey, the treaty has no significant traction in allied public opinion. As previously mentioned, opinion polls that are deliberately conducted without context mean very little, all the more so as nuclear fears do not currently rank high among the Western populace. ${ }^{35}$ Hence, like previous initiatives such as 'Global Zero', the TPNW movement, despite being awarded the Nobel Peace Prize in 2017, remains a narrow elite project without significant political momentum. Since no nuclear power or any

31 'North Atlantic Council Statement as the Treaty on the Prohibition of Nuclear Weapons Enters Into Force', Press Release (2020) 131, NATO, 15 December 2020, www.nato.int/cps/en/natohq/ news_180087.htm?selectedLocale=en.

32 Tweet by George Perkovich (@perkovichG), 16 December 2020, 4.14 pm.

33 See Brad Roberts, 'Ban the Bomb? Or Bomb the Ban?', European Leadership Network Policy Brief, 22 March 2018, www.europeanleadershipnetwork.org/wp-content/uploads/2018/03/180322Brad-Roberts-Ban-Treaty.pdf.

34 See, for example: 'Inquiry into the Consequences of a Swedish Accession to the Treaty on the Prohibition of Nuclear Weapons', Swedish Foreign Ministry, 2019, www.regeringen.se/48f047/ contentassets/756164e2ca3b4d84a3070a486f123dbb/rapport_execsummary.pdf.

35 For a typical example of hyping an inconsequential poll, see International Campaign to Abolish Nuclear Weapons, 'NATO Public Opinion on Nuclear Weapons', January 2021, d3n8a8pro7vhmx. cloudfront.net/ican/pages/234/attachments/original/1611134933/ICAN_YouGov_Poll_2020. pdf?1611134933. A more nuanced analysis is provided by Manuel Lafont Rapnouil, Tara Varma and Nick Witney, 'Eyes Tight Shut: European Attitudes towards Nuclear Deterrence', European Council on Foreign Relations, 19 December 2018, ecfr.eu/special/eyes_tight_shut_european_attitudes_towards_ nuclear_deterrence/. On the current public disinterest in nuclear matters in the US, see Ashley Lytle and Kristyn L. Karl, 'Understanding Americans' Perceptions of Nuclear Weapons, Risk and Subsequent Behavior', International Journal of Communication 14, 2020, 299-323. For a review of nuclear attitudes in the 1980s, see Yost, 'The Delegitimization of Nuclear Deterrence?'. 
ally benefiting from extended nuclear deterrence has signed the treaty, it is likely to remain a symbolic and aspirational document rather than a true game-changer in global disarmament. ${ }^{36}$

The possibility that a future government in a NATO member state may change its mind and seek to sign the TPNW or effect major changes in NATO's nuclear policy can never be ruled out. However, in a strategic environment characterised by increasing great power competition, allied governments are likely to give preference to allied solidarity rather than undermine that very solidarity by opposing what is likely to remain an important element of NATO's political and military acquis.

The asymmetry between nuclear and non-nuclear allies in terms of military power and status may be profound, and occasionally has led to allied disagreements over nuclear strategy. However, even though the US is the linchpin of NATO's nuclear deterrent, and thus is primus inter pares, it cannot determine alliance strategy or declaratory policy on its own. Recognising that political unity is of key importance, the US has to take into account the sensitivities of its non-nuclear allies, in terms of both strategy development and declaratory policy. The latter remains influenced by the primacy of communicating allied unity and of reassuring allied publics. While this may come at the expense of terminological precision or tailored messaging vis-a-vis an opponent, the alternative-a highly emotional and politically counterproductive debate within allied countries-would seem a net loss. This is all the truer in an age in which the (dis-)information space is increasingly dominated by social media. In such an environment, reassuring one's allies must take precedence over impressing one's adversaries with tough public messages intended to show 'resolve'.

This need for reassurance should not be misunderstood as a licence for passivity, however. In an era in which nuclear deterrence is being questioned politically, morally, technologically and legally in Western societies, the political class of a country that intends to retain nuclear protection must be able to make a cogent case for nuclear deterrence, without appearing to trivialise its risks. This requires that political leaders

36 See Jean-Baptiste Jeangene Vilmer, 'The Forever Emerging Norm of Banning Nuclear Weapons', Journal of Strategic Studies 2020, 1-27, doi.org/10.1080/01402390.2020.1770732. 
make a conscious effort to engage in public discussions about the nuclear dossier. ${ }^{37}$ It also requires like-minded nations to reinforce their case for nuclear deterrence by stating it collectively. In the end, communicating the reality of cohesion between nuclear and non-nuclear allies-across the North Atlantic and the Asia-Pacific-may send the strongest message in terms of both deterrence and reassurance: a united West.

37 See the contribution of Brad Roberts in this volume. 
This text is taken from Alliances, Nuclear Weapons and Escalation: Managing Deterrence in the 21st Century, edited by Stephan Frühling and Andrew O'Neil, published 2021 by ANU Press, The Australian National University, Canberra, Australia.

doi.org/10.22459/ANWE.2021.15 